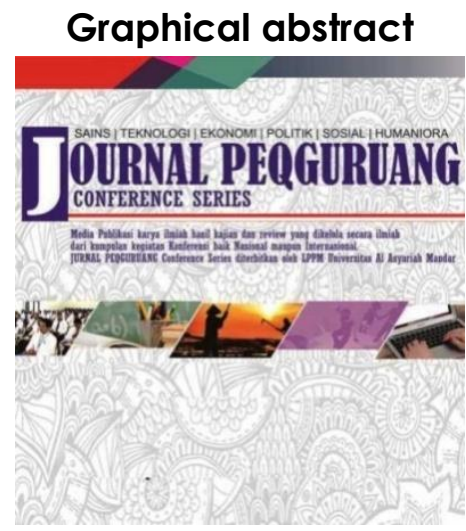

\title{
TINJAUAN HUKUM ISLAM TERHADAP JUAL BELI HAMPA (STUDI KASUS DUSUN MAPILLI BARAT KECAMATAN LUYO KABUPATEN POLMAN )
}

\author{
${ }^{1 *}$ Ahsan Abdissalam, ${ }^{2}$ Busyra, ${ }^{3}$ M. Anwar \\ Hukum Ekonomi Syariah Fakultas Agama Islam \\ Universitas Al Asyariah Mandar \\ Corresponding author: \\ Ahsanabdissalam@gmail.com
}

\begin{abstract}
The objectives of this study are: 1) To find out how the mechanism and practice of buying and selling hampa in West Mapilli Village 2) To find out how Islamic law reviews the arguments about the law of hampa buying and selling in West Mapilli Village. This type of research uses qualitative research, in this case qualitative research aims to explain a phenomenon as deeply as possible by collecting the deepest data that shows the importance of depth and detail of the data being studied (source Binus University Bandung). The results of the study indicate that Referring to the explanation of the book of buying and selling that the author has summarized on the previous page, hampa buying and selling fulfills several conditions related to the law, namely the existence of goods being traded in another sense that the goods are not supernatural, but the explanation of the book does not only reach whether there is a limit to the goods being traded or not, it is still necessary to consider several other aspects such as benefits, clarity, and fraud, as well as the absence of a disadvantaged party. As previously explained, the company no longer uses cocoa dregs (hampa) from the sorting results, or the cocoa dregs no longer have a selling value in the company, based on the explanation of the previous book, all buying and selling that does not have legal benefits is not allowed In the case of empty buying and selling, the community still uses the dregs, but it is used as a ballast which incidentally contains an element of gharar or ambiguity because it uses something that is no longer used in the company.
\end{abstract}

Kata Kunci : Islamic economic perspective, buying and selling empty

\begin{abstract}
Abstrak
Tujuan Penelitian ini adalah : 1) Untuk Mengetahui Bagaimana mekanisme dan praktek jual beli hampa yang ada di Desa Mapilli Barat 2) Untuk mengetahui bagaimna tinjauan hukum Islam mengenai dalil-dalil tentang hukum jual beli hampa yang ada di Desa Mapilli Barat. Jenis penelitian ini menggunakan jenis penelitian kualitatif, dalam hal ini penelitian kualitatif bertujuan untuk menjelaskan suatu fenomena dengan sedalam-dalamnya dengan cara melakukan pengumpulan data yang sedalam-dalamnya yang menunjukkan pentingnya kedalaman dan detail suatu data yang diteliti (sumber Binus University Bandung). Hasil penelitian menunjukkan bahwa Merujuk pada penjelasan kitab jual beli yang telah penulis rangkum pada halaman sebelumnya, jual beli hampa memenuhi beberapa syarat terkait hukumnya, yakni adanya barang yang di perjual belikan dalam artian lain barang tersebut tidak bersifat ghoib, namun penjelasan kitab tidak hanya sampai pada batas ada tidak nya barang yang di perjual belikan tersebut, masih perlu mempertimbangkan beberapa aspek lain seperti manfaat, kejelasan, dan kecurangan, serta tidak adanya pihak yang di rugikan. Seperti yang telah di paparkan sebelumnya bahwa pihak perusahaan sudah tidak menggunakan ampas kakao (hampa) dari hasil sortir, atau ampas kakao tersebut sudah tidak memiliki nilai jual di perusahaan, berdasar pada penjelasan kitab sebelumnya, segala jual beli yang tidak mempunyai manfaat hukumnya tidak di perbolehkan, pada kasus jual beli hampa, masyarakat masih memanfaatkan ampas tersebut, namun di pergunakan sebagai alat pemberat yang notabenenya mengandung unsur gharar atau ketidak jelasan sebab menggunakan sesuatu yang tidak di pergunakan lagi di perusahaan.
\end{abstract}

Kata Kunci : Prespektif Ekonomi Islam,Jual Beli hampa

\section{Article history}

DOI: https://dx.doi.org/10.35329/ip.v3i2.1995

Received : 20 Juli 2021 | Received in revised form : 28 Agustus 2021 | Accepted : 25 September 2021 


\section{PENDAHULUAN}

Dalam Islam prinsip utama dalam kehidupan umat manusia adalah Allah.SWT. Merupakan zat yang Maha Esa, Dia adalah satu satunya Tuhan dan pencipta seluruh alam semesta, sekaligus pemilik, penguasa serta pemelihara tunggal hidup dan kehidupan seluruh makhluk yang tiada bandingan dan tandingan, baik di dunia maupun di akhirat. Dia subbuhun dan quddusun,yakni bebas dari segala kekurangan ,kesalahan,kelemahan, dan berbagai kepincangan lainnya, serta suci dan bersih dalam segala hal. Sementara itu, manusia merupakan makhluk Allah SWT, yang diciptakan dalam bentuk yang paling baik sesuai hakikat wujud manusia dalam pengabdian kepada sang Maha Pencipta Allah SWT.

Seperti halnya Al-Qu'ran Rasulullah SAW, juga menempatkan ajaran berfikir dan menggunakan akal sebagai ajaran yang jelas dan tegas. (Karim, Sejarah Pemikiran Ekonomi Islam, 2004). Berbagai praktik dan kebijakan ekonomi yang berlangsung pada masa Rasulullah saw dan al-khulafa al-Rasydun merupakan contoh empiris yang di jadikan pijakan bagi para cendikiawan muslim dalam melahirkan teori-teori ekonominya. Satu hal yang jelas, fokus perhatian mereka tertuju pada pemenuhan kebutuhan, keadilan, efisiensi,pertumbuhan, dan kebebasan yang tidak lain merupakan objek utama yang menginspirasikan pemikiran ekonomi Islam sejak masa awal.

Pada penelitian terdahulu terdapat beberapa yang meneliti dari segi analisa, salah satunya Jerry Nurvian Batubara. Beliau meneliti tentang "Analisis Perdagangan Kakao Indonesia di Pasar International" dengan konsentrasi program studi Ilmu Ekonomi,Fakulas Ekonomi Universitas Islam Indonesia Yogyakarta. Berdasarkan hasil analisis dan pembahasan yang telah di lakukan pada bab sebelumnya, maka dapat di ambil beberapa kesimpulan sebagai berikut Variabel Jarak Ekonomi (Ecodis) berpengaruh signifikan dan negatif terhadap Ekspor Kakao Indonesia. Artinya semakin jauh jarak antara dua negara yang melakukan hubungan perdagangan internasional (ekspor-impor) maka akan semakin mahal biaya yang harus dikeluarkan oleh negara pengimpor. Dan untuk negara pengekspor volume penjualannya akan berkurang karna biaya untuk mendapatkan barang ekspor terebut menjadi cukup mahal. Hal ini sesuai dengan teori dan hipotesa. (Batubara, p. 2018)

Berkaitan dengan hal tersebut, melihat kondisi hari ini praktek muamalah dalam hal penerapan sistem ekonomi Islam yang ada, bermula dari transaksi jual beli yang menerapkan sistem Islam, maupun perbankan yang telah menerapkan sistem syariah. Dalam jual beli tentunya mempunyai beberapa pertimbangan dalam melakukan transaksi, perlu mengetahui rukun dan syarat yang harus di penuhi untuk memenuhi syarat sah jual beli. Hal tersebutlah yang membuat penulis tertarik untuk meneliti lebih dalam mengenai sistem jual beli yang telah di lakukan oleh masyarakat banyak khususnya daerah Sulawesi barat, Kabupaten Polman, Kecamatan luyo, Desa Mapilli Barat mengenai "Tinjauan Hukum Islam terhadap sistem jual beli hampa (ampas coklat)" yang dilakukan beberapa masyarakat di Desa Mapilli Barat. Untuk mengetahui status hukum dan kebolehan terhadapa jual beli hampa, penulis perlu mengetahui beberapa aspek terkait mekanisme jual beli hampa yang ada di Desa Mapilli Barat sebelum lebih jauh menggali terkait kebolehan praktek jual beli hampa dalam tinjauan Hukum Islam

\section{METODE PENELITIAN}

Pada penelitian kali ini, Penulis menggunakan jenis penelitian kualitatif dalam liter artur metode penelititan, kualitatif tidak hanya di maknai sebagai jenis data,tetapi juga berhubungan dengan analisis data dan interpretasi atas objek kajian. Secara historis, implementasi penelitian kualitatif bermula dari pengamatan sebagai perbandingan pada penelitian kuantitatif,pengamatan berkenaan dengan pengukuran tingkatan dengan suatu cirri tertentu.Namun penelitian kuaitatif menunjuk pada segi alamiah yang di pertentangkan dengan kuantum ( jumlah ). Maksudnya, Penelitian kualitatif tidak di maksudkan untuk mengadakan penghitungan secara kuantitas. Hal ini berbeda dengan pengamatan pada penelitian kuantitatif yang pengamatannya berdasarkan perhitungan persentase. (Prastowo, 2011)

Penelitian yang dilakukan menggunakan metode analisis deskriptif,dimana penelitian yang dilakukan yaitu memecahkan masalah yang ada dilapangan berdasarkan fakta dan data secara actual dan mendalam, melakukan pemusatan masaah yang terjadi pada masa sekarang ${ }^{1}$

Penulis melakukan penelitian di Desa Mapilli Barat Kecamatan Luyo Kabupaten Polewali Mandar. Adapun objek penelitian penulis ialah masyrakat yang menggeluti usaha jual beli hampa serta pihak pegawaiperusahaan PT Bumi Surya yang berafiliasi pada bidang usaha kakao yang ada di desa Mapilli Barat 


\section{HASIL DAN PEMBAHASAN}

Pada dasarnya hampa berasal dari proses pemisahan antara biji kakao berkualitas yang telah di keringkan dengan kualitas biji kakao yag tidak memenuhi standar kualitas kakao pada umumnya. Sebab tidak semua dalam buah kakao mempunyai isi yang baik, faktor lain ialah rusaknya kakao. Maka Dari itu dalam hal pelaksanaan pengeringan biji kakao yang dilakukan pengusaha, terdapat pemisahan antara biji kakao yang baik dengan biji kakao yang kopong atau yang kualitas rendah (Red: Hampa). Dari proses ini para pedagang mengambil biji kakao yang tidak berkualitas, membeli dengan harga murah kemudian di olah dan diseleksi kembali berdasarkan klasifikasi kualitas hampa.

Dari hasil riset atau wawanara yang di lakukan penulis pada masyarakat desa Mapilli Barat terkait bisnis hampa, menghasilkan beberapa pengertian :

“ itu hampa ada beberapa yang bagus ada juga yang tidak kalau kualitas pertama itu masih bagus masih bentuk coklat tapi kopong, kualiats kedua itu ndak terlalu bagusmi bentuknya tapi masih bisa dijual, kalau kualitas ketiga itu unar mi masih digunakan juga masih dijual kalau kualitas ke empat itu pasir nya mi itu masih dijual juga biasanya tapi nabawa kemamuju biasa dijual. Kalau kualitas pertama itu biasa dijual Rp.15.000 sampai Rp.20.000 kalau kualitas kedua itu Rp. 10.000 sampai Rp. 15.000 kalau kualiats ketiga itu biasa Rp.3000 2

a. Kualitas Pertama

Biji hampa Kualitas pertama merupakan biji kakao yang masih memiliki bentuk utuh seperti coklat berkualitas pada umumnya, namun yang membedakan ialah hampa kualitas pertama ini, memiliki isi yang kopong atau tidak sempurna namun sebagaian pedagang mengatakan bahwa biji hampa ini masih mempunyai nilai jual di kalangan pedagang kecil yang memasok kakao kegudang

b. Kualitas kedua

Biji hampa kualitas kedua merupakan biji kakao yang sebagian besar sudah tidak bebentuk biji coklat pada umumnya, terdapat beberapa bagian tekstur biji kakao yang terlihat hancur, namun di kalangan pedagang kecil juga masih memiliki nilai Jual. c. Kualitas ketiga

Kualitas ketiga ini tidak termasuk dalam klasifikasi biji kakao pada umumnya karena ia merupakan tangkai dari biji pada buah kakao dan masyarakat umum menyebutnya sebagai unar, karena unar merupakan tangkai biji kakao yang sudah di keringkan dan berwarna seperti kakao pada umumnya, namun di kalangan pedagang kecil masih memiliki nilai jual namun tentunya berbeda dengan harga hampa yang di jelaskan di atas.

d. Kualitas keempat

Kualitas keempat ini merupakan limbah yang berasal dari pemisahan kakao dan ampas yang ada pada kakao, tidak termasuk dalam klasifikasi kakao pada umumnya sebab ia merupakan sisa-sisa dari pemisahan antara tangkai biji dan ampas.

Jadi kesimpulan dari pengklasifikasian yang di lakukan oleh para pedagang hampa, hampa merupakan biji kakao yang memiliki kualitas tidak sempurna dalam satu buah kakao. Biji dari hampa ini tidak memiliki kualitas yang baik seperti pada umumnya, biasanya ditandai dengan kakao yang kopong tak berisi serta bentuk yang hampir tidak sama dengan kakao pada umumnya. Kakao kopong inilah yang dimaksud dengan hampa namun masyarakat yang menggeluti bisnis ini mengatakan bahwa hampa masih memiliki manfaat untuk diperjual belikan.

Para pedagang hampa tersebut memiliki dua opsi penjualan: pertama, hampa dibeli secara terpisah dari kakao yang baik kualitasnya kemudian di jual kembali ke pedagang kakao yang ada di Desa Mapilli barat dan kedua, hampa yang dibeli dari petani dicampur langsung dengan kakao kualitas murni yang di miliki oleh pedagang hampa kemudian di pasarkan ke Gudang. Dalam hal ini sangat menguntungkan bagi pembeli hampa.

Hampa atau coklat yang kopong tersebut dibeli dari para petani kakao, kemudian dijual kembali kepada petani sekaligus pedagang kakao yang ada di masyarakat desa Mapilli Barat tentunya melalui tahapan seleksi seperti yang di paparkan di awal. Mengacu pada hasil wawancara yang di lakukan oleh peneliti terhadap para narasumber hampa tersebut mempunyai nilai jual dan masih bisa di manfaatkan sebagai barang jualan. Para pedagang tersebut membeli hampa ( ampas kakao ) dari petani yang telah memisahkan kualitas kakao yang baik dan kopong umtuk di pasarkan ke gudang kakao, maka dari itu para pedagang hampa, membeli ampas kakao yang sudah tidak digunakan oleh para petani tersebut.

Ketika mengacu pada kualitas gudang kakao, maka hampa atau ampas kakao yang kopong tersebut, jika di edarkan ke pabrik maka pihak pabrik tidak akan menerimanya, sebab tidak 
memenuhi standar dari kualitas kakao yang siap di edarkan kepasaran, namun bisa berguna sebagai alat untuk menambah berat dari kakao kualitas murni agar keuntungannya semakin besar bagi pedagang kakao yang ada dimasyarakat. Hampa yang telah dibeli oleh pedagang kakao dari pedagang hampa Ini kemudian digunakan sebagai bahan untuk mencampur biji kakao yang kualitasnya baik, dengan ampas kakao yang telah dibeli sebagai media tambahan untuk memberatkan timbangan juga sebagai tambahan keuntungan nantinya bagi pedagang coklat dimasyarakat, sebab pihak pabrik itu hanya mengambil kakao yang baik saja, karna di pabrik kakao sendiri dalam hal pengelolaan nantinya, ampas itu akan terpisah dan dibuang melalui hasil seleksi pabrik.

pedagang hampa yang telah di wawancarai oleh peneliti memaparkan bahwa, keuntungan yang didapat dari penjualan hampa cukup besar, sebab harga hampa yang di beli pada petani kakao itu sekitar Rp1.000-3.000/kg dan apabila hampa tersebut telah di seleksi berdasarkan kualitasnya maka harganya bisa mencapai pada kisaran Rp 15.000 - 20.000 / kg untuk hampa kualitas pertama, Rp.10.000 -15.000 / $\mathrm{kg}$ untuk hampa kualitas kedua, Rp.3.000 / kg untuk hampa kualitas ketiga, Rp.500 /kg untuk hampa kualitas keempat. Maka dari itu hampa yang dibeli dari petani kakao pada kisaran Rp.3.000/ kg, bisa menghasilkan angka pendapatan yang jauh dari harga modal awal, sebab apabila hampa telah di klasifikasikan berdasarkan kualitasnya, maka semua kualitas hampa mempunyai harga masing-masing.

PT. Bumi Surya merupakan sebuah perusahaan yang berada di Desa Mapilli Barat dan berafiliasi pada bidang Pertanian khususnya Kakao. Berdasarkan hasil wawancara yang dilakukan penulis dengan Kordinator Treceability perusahaan yakni Pak Toni, beliau menuturkan bahwa, para pedagang bisa menjual kakao ke perusahaan cabang di tiap tiap daerah. Dari perusahaan cabang, kakao yang telah di beli selanjutnya akan di distribusikan ke gudang perusahaan pusat yang ada di Polewali Mandar khusunya di Desa Mapilli Barat. Barang yang telah masuk ke gudang tidak semerta-merta langsung di simpan ke gudang, akan tetapi melalui beberapa tahapan pemeriksaan. Proses pertama yang di lakukan adalah proses penimbangan terhadap massa kakao pada proses ini juga di lakukan pengecekan kadar basah dan kering terhadap biji kakao. Jika kadar air pada biji kakao tinggi maka potongannya juga akan tinggi namun sebaliknya jika kadar kakao memenuhi syarat maka pemotongan harga juga semakin sedikit, dari proses inilah harga sudah bisa di tentukan oleh pihak perusahaan.
Setelah melalui proses penimbangan, maka alur selanjutnya adalah proses pemeriksaan kualitas biji kakao dengan cara mensortir kakao agar terpisah dari kotoran dan kualitas biji kakao yang kurang baik.. Dari proses inilah akan terjadi pemisahan antara ampas (hampa) dengan biji kakao yang memenuhi kualitas standar gudang pada umumnya. Sebab kakao yang di pasarkan harus memenuhi kualitas yang telah di tetapkan,kemudian kotoran atau kualitas biji kakao yang tidak memenuhi syarat di simpan di gudang dan menurut pemaparan dari narasumber bahwa ampas tersebut tidak lagi di gunakan.

Melihat kembali penjelasan kitab jual beli yang telah penulis rangkum pada halaman sebelumnya, jual beli hampa memenuhi beberapa syarat terkait hukumnya, yakni adanya barang yang di perjual belikan dalam artian lain barang tersebut tidak bersifat ghoib, namun penjelasan kitab di atas tidak hanya sampai pada batas ada tidak nya barang yang di perjual belikan tersebut, masih perlu mempertimbangkan beberapa aspek lain seperti manfaat, kejelasan, dan kecurangan, serta tidak adanya pihak yang di rugikan. Seperti yang telah di paparkan sebelumnya bahwa pihak perusahaan sudah tidak menggunakan ampas kakao (hampa) dari hasil sortir, atau ampas kakao tersebut sudah tidak memiliki nilai jual di perusahaan, berdasar pada penjelasan kitab sebelumnya, segala jual beli yang tidak mempunyai manfaat hukumnya tidak di perbolehkan, pada kasus jual beli hampa, masyarakat masih memanfaatkan ampas tersebut, namun di pergunakan sebagai alat pemberat yang notabenenya mengandung unsur gharar atau ketidak jelasan sebab menggunakan sesuatu yang tidak di pergunakan lagi di perusahaan. Dari penjelasan Kitab di atas, penulis dapat menyimpulkan bahwa pada dasarnya Jual beli di perbolehkan selama tidak mengandung unsur ketidak jelasan (gharar), menipu serta Judi. Selama sesuatu yang di perjual belikan itu ada atau dalam artian lain tersedia, kemudian tidak ada pihak yang di rugikan antara si pembeli dan penjual. Hal ini tentunya di dukung oleh penjelasan dalam Al-Qu'ran yang telah di paparakan penulis pada halaman sebelumnya.

Seperti pada kasus jual beli pisau, jika menjual pisau kepada orang yang memerlukannya sebagai kebutuhan dapur maka hukumnya di perbolehkan, namun jika menjualnya kepada orang yang ingin menggunakan pisau tersebut untuk membunuh maka hukumnya tidak boleh atau haram. Jika ampas tersebut di perjual belikan untuk sesuatu yang lain seperti keperluan ternak atau bercocok tanam maka tidak ada unsur gharar di dalamnya namun jika di perjual belikan untuk memberatkan timbangan maka hukumnya tidak boleh, sebab memanipulasi timbangan dengan 
sesuatu yang tidak di gunakan lagi di perusahaan. Dalam kasus jual beli hampa tentunya mengandung unsur memberatkan timbangan, tentunya hal tidak di perbolehkan. Hal ini di perkuat dalam Al-Qur'an Surah Al-Mutaffifin ayat 1 :

\section{Terjemahnya :}

Kecelakaan besarlah bagi orang-orang yang curang.

pada awal surah ini disebutkan salah satu hal yang paling banyak terjadi dalam hubungan antar manusia yakni menyangut ukuran. Salah satu dosa yang terbesar adalah menyangkut ukuran dan timbangan. Kecelakaan, kebinasaan dan kerugian akan di alami oleh pelaku yang melakukan kecurangan dalam interaksi ini. Itu dapat dirasakan oleh pelaku perdangangan. Siapa yang dikenal curang dalam penimbangan maka pada akhirnya yang bersedia berinteraksi dengannya hanyalah orang rang yang melanjutkan hubungan dengannya, dan ini adalah pangkal .kecelakaan dan kerugian duniawi. (Shihab, 2003) Pada intinya apapun bentuk jual beli yang memanfaatkan kecurangan, adanya sumber ketidak jelasan serta adanya pihak yang dirugikan seperti yang penulis telah paparkan pada penjelasan sebelumnya terkait dengan jual beli maka hukumnya tidak boleh / haram. Hal ini di perkuat oleh beberapa dalil mengenai jual beli yang telah terpaparkan di atas.

Pada intinya apapun bentuk jual beli yang memanfaatkan kecurangan, adanya sumber ketidak jelasan serta adanya pihak yang dirugikan seperti yang penulis telah paparkan pada penjelasan sebelumnya terkait dengan jual beli maka hukumnya tidak boleh / haram. Hal ini di perkuat oleh beberapa dalil mengenai jual beli yang telah terpaparkan di atas.

\section{SIMPULAN}

Hasil penelitian yang telah dilakukan penulis pada Desa Mapilli Barat Kecamatan Luyo Kabupaten Polewali Mandar, berdasar pada rujukan dalil dan kitab serta Cendikiawan muslim maka terdapat beberapa kesimpulan yang menunjukkan bahwa :

a. hampa berasal dari proses pemisahan antara biji kakao berkualitas yang telah di keringkan dengan kualitas biji kakao yag tidak memenuhi standar kualitas kakao pada umumnya. Sebab tidak semua dalam buah kakao mempunyai isi yang baik, faktor lain ialah rusaknya kakao. Maka Dari itu dalam hal pelaksanaan pengeringan biji kakao yang dilakukan pengusaha, terdapat pemisahan antara biji kakao yang baik dengan biji kakao yang kopong atau yang kualitas rendah (hampa). Dari proses ini para pedagang mengambil biji kakao yang tidak berkualitas, membeli dengan harga murah kemudian di olah dan diseleksi kembali berdasarkan klasifikasi kualitas hampa yang telah di paparkan. Pedagang atau petani yang memasarkan kakao nya ke gudang, akan melalui beberapa tahap penyeleksian yakni penimbangan kakao, setelah melalui proses penimbangan maka yang di lakukan selanjutnya adalah pengecekan kualitas, kadarbasah dan kering dari kakao, dari proses kadar ini harga bisa ditentukan berdasarkan kualitasnya. Kemudian tahap terakhir yang dilakukan adalah tahap sortir. Tahap sortir merupakan proses pemisahan antara biji kakao yang berkualitas dan biji kakao yang kopong, kakao yang berkualitas akan siap di pasarkan, sedangkan biji kakao yang kopong menurut penjelasan pihak perusahaan tidak di gunakan lagi. Jadi kesimpulan dari hasil penelitian yang di lakukan penulis bahwa, hampa sudah tidak memiliki nilai jual di perusahaan, dan hanya di perjual belikan di tataran masyarakat sebagai campuran pemberat.

b. Merujuk pada penjelasan kitab jual beli yang telah penulis rangkum pada halaman sebelumnya,jual beli hampa memenuhi beberapa syarat terkait hukumnya, yakni adanya barang yang di perjual belikan dalam artian lain barang tersebut tidak bersifat ghoib, namun penjelasan kitab di atas tidak hanya sampai pada batas ada tidak nya barang yang di perjual belikan tersebut, masih perlu mempertimbangkan beberapa aspek lain seperti manfaat, kejelasan, dan kecurangan, serta tidak adanya pihak yang di rugikan. Seperti yang telah di paparkan sebelumnya bahwa pihak perusahaan sudah tidak menggunakan ampas kakao (hampa) dari hasil sortir, atau ampas kakao tersebut sudah tidak memiliki nilai jual di perusahaan, berdasar pada penjelasan kitab sebelumnya, segala jual beli yang tidak mempunyai manfaat hukumnya tidak di perbolehkan, pada kasus jual beli hampa, masyarakat masih memanfaatkan ampas tersebut, namun di pergunakan sebagai alat pemberat yang notabenenya mengandung unsur gharar atau ketidak jelasan sebab menggunakan sesuatu yang tidak di pergunakan lagi di perusahaan. 


\section{DAFTAR PUSTAKA}

Nurvian Batubara Jerry, (2018), Analisi Perdagangan Kakao Indonesia di Pasar International, Pdf, Skripsi, Yogyakarta Fakultas Ekonomi Universitas Islam Indonesia Yogyakarta,

Azwar karim Adiwarman, (2004), Sejarah pemiki ran ekonomi islam Cet.VIII:Depok:PT Rajagrafindo Persada, Ed. ke-4,

Prastowo Andi, (2011), Metode penelitian kualitatif dalam perspektif rancangan penelitian Cet.I,:Jogjakarta:Ar-Ruzz Media.

Shihab M Quraish, (2003), TAFSIR AL$M I S B A H$,Cet I:Jakarta. Lentera Hati,Jakart a, 